tunnellings. Mr. Fuller describes his observations upon the behaviour of the winged sexual forms belonging to six different species. He shows that the belief that the aerial migration has for its object the prevention of interbreeding is not necessarily true, since the flights frequently comprise individuals of both sexes which readily pair. This same feature has also been observed by the reviewer in the case of a Himalayan Termite. Intercrossing occurs at times among individuals of different nests, but Mr. Fuller concludes that the real object of the production of sexual forms in such vast numbers is in order to perpetuate the species, which suffers immense mortality during the annual exodus. Some sixty-four pages are devoted to observations on the nest-building habits and general economy of thirteen species of Termites, and details of the various types of nests are well illustrated on the accompanying plates. The remainder of the paper comprises a systematic account of species, chiefly belonging to the genera Hodotermes, Termes, and Eutermes. The characters of the soldiers and workers are well described, but unfortunately no accounts of the winged forms are included, and it is to be hoped that the author will make these the subject of a further memoir.

Mr. J. Hewitt contributes a paper on South African Arachnida, mostly based on specimens in the Albany Museum. Altogether three genera, eleven species, and one variety are recorded as new, and the most interesting feature brought to light is the discovery of two new genera of marine spiders taken near Cape Town. The remainder of the journal is occupied by two short papers by Dr. Warren, one dealing with the tendency of the Saturniid moth, Melanocera menippe, Westw., to exhibit parthenogenesis, and the other with an extension of his previous observations upon hybrid cockatoos.

A. D. Imms.

\section{THE CROYDON NATURAL HISTORY} SOCIETY.

THE Transactions of the Croydon Natural History and Scientific Society for I915, a copy of which has just reached us, contain a particularly good paper by Mr. G. M. Davies on the rocks and minerals of the Croydon regional survey area. The paper runs to 44 pages, and includes a careful series of analyses of rock-specimens from the Weald Clay and all the more recent formations. Reference is made to the discovery of the Marsupites-zone of the chalk at Russell Hill, Purley, and to the decomposition of marcasite, which gives rise to the soft masses of hydrated iron oxide ("red ochre") so frequent in the chalk. A few sarsens are noted as occurring in the neighbourhood. Granules and grains of zinc-blende and galena are noted as occurring in fuller's-earth at Redhill and Nutfield. The number of minerals found in residues is somewhat surprising, and a complete list is given. The regional survey, under the direction of Mr. C. C. Fagg, shows satisfactory progress, and in connection with it Baldwin Latham has prepared a map showing the site of the five Bounnes which flow in the area.

Mr. William Whitaker describes an extraordinary outlier of Blackheath pebble-beds at Tandridge Hill. With the pebbles are patches of fairly large unworn flints, resembling in shape flints as found in chalk-pits. Flints, in any intermediate stage of weathering are not. found, and the two cannot have been produced by the same agency. It is thought that, during or after the deposition of the rounded Blackheath beds, the unworn flints have been quietly removed from the chalk.during the dissolution of.the latter, and left near to.their original position.
The extension of the outlier so far south is of interest, but especially is it so in that though the uppermost outlier is nearly $800 \mathrm{ft}$. O.D., lthe lowest extension is $200 \mathrm{ft}$. lower, on the face of the escarpment of the chalk. Hence we here find Eocene beds resting on lower chalk, an occurrence unknown elsewhere. The conclusion come to is that long-continued solution of pebble-covered chalk took place on a large scale, and the pebble-beds were very gradually let down. There was no evidence of faulting. It is fairly certain they could not have been originally deposited on the middle and lower chalk as now found.

The usual valuable meteorological statistics for 1915, compiled by Mr. F. Campbell-Bayard, with rainfall day by day from IO4 stations, is of value to water-economists. In a paper summarising the fossil records of Ginkgo biloba and its ancestors, Mr. E. A. Martin remarks that there has been of late a considerable increase of small specimens of this tree in this country. Hithento this "living fossil," as Seward calls it, has been represented chiefly by male trees, and it is hoped a balance may be restiored now that it is included in florists' eatalogues.

\section{THE LAKE VILLAGERS OF GLASTONBURY.1}

THE Lake Village of Glastonbury consisted of between eighty and ninety round huts surrounded by a stockade, and planted for security at the edge of the sheet of water, that is now represented by the peat in the marshes, extending from Glastonbury westward to the sea. The inhabitants smelted iron and made various edged tools and weapons-axes, adzes, gouges, saws, sickles, bill-hooks, daggers, swords, spears, etc. They also smelted lead ore from the Mendip Hills, and made net-sinkers and spindle-whorls. They probably carried on the manufacture of glass beads and rings and other personal ornaments. They were also workers in tin and bronze. It is likely that the beautiful Glastonbury bowl was made in the settlement, since unused rivets of the same type as those of the bowl have been commonly met with. They were expert spinners and weavers, carpenters and potters, using the lathe in both industries. The discovery of a wooden wheel, with beautifully turned spokes, proves that they possessed wheeled vehicles, while the snaffle-bits of iron imply the use of the horse. Their commerce was carried on partly by land, and the possession of canoes gave them the use of the waterways. They were linked with other settlements by the road running due east from Glastonbury, that formed a part of the network of roads traversing the country in the prehistoric Iron age, more especially with the lead mines and the fortified oppida, or camps, of Mendip and of the rest of the county. They were also linked with the Bristol Channel by a waterway along the line of the river Brue, and along this was free communication with the oppidum of Worlebury, then inhabited by men of their race.

The lake villagers were undoubtedly in touch with their neighbours by sea and by land. Their jet probably came from Yorkshire; their Kimmeridge shale from Dorset; the amber from the eastern counties, or from the amber coast south of the Baltic. The cocks for fighting. were probably obtained from Gaul, and the oblong dice are identical with those used in Italy in Roman times. Some of the designs on their pottery are from the south, and the bronze mirrors are probably of Italo-Greek origin. The technique of the

1 Abridged from a paper read before the Literary and Philosophical Society

No. 2440, VOL. 97] 